\title{
The Effect of PER and Dividend Yield on Banking Share Prices The Idx In 2020
}

\author{
Syarif Hidayah Lubis ${ }^{1}$, Agus Defri Yando ${ }^{2}$ \\ ${ }^{1}$ Universitas Universal \\ ${ }^{2}$ Universitas Putera Batam \\ hidayahsyarif@gmail.com
}

\begin{abstract}
The purpose of this study is to see the effect of PER and Dividend Yield on banking stock prices in 2020. The method used in this study is a quantitative type using secondary data using a target population of 44, while for the determination of the population of the Non-Sampling type. The probability is 16 and the analysis used is SPSS version 22. The results in this study found that PER partially has no effect on share prices, dividend yield partially has no effect on price Shares, PER and Dividend Yield simultaneously have no effect on Stock Prices
\end{abstract}

Keywords:PER, Dividend Yield, Stock Price

\section{PENDAHULUAN}

Investasi dalam pasar modal saat ini menjadi salah satu bentuk investasi yang primadona, terlebih lagi dalam masa pandemic corona virus 2019 (Covid-19) dimana konsdisi ini memukul ekonomi secara gelobal yang berefek pada ekonomi mikro masyarakat.Oleh sebab itu dengan adanya investasi diharapkan membaiknya kembali ekonomi masyarakat secara perlahan. Ada berbagai macam bentuk investasi dalam pasar modal tersebut salah satunya yang banyak diminati adalah investasi dalam bentuk saham dimana masyarakat (investor) yang akan berinvestasi tidak memerlukan banyak modal, harga sebuah saham dalam bentuk per lot saat ini yang paling termurah berada diharga 50 atau bila dikompersi dalam bentuk nominal sebesar Rp. 5000/lot dan tertinggi berkisar 45.000 atau Rp4.500.000/lot. Dengan nilai investasi yang cukup terjangkau tersebut membuat masyarakat selaku investor sangat mudah sekali untuk berinvestasi, ,mengingat cara investasi lain memerlukan banyak modal seperti rumah, tanah dan lainnya. (Rahmadewi \& Abundanti, 2018). Apabila dilihat juga dari kenaikan harga-harga saham perbankan karena banyak peminatnya selama 5 tahun terakhir mengalami pertumbuhan yang berfluaktif seperti berikut ini

Tabel 1 Pertumbuhan Rata-rata Harga Saham Perbankan

$\begin{array}{lrr}\text { TAHUN } & \text { HARGA } & \text { PERTUMBUHAN }\end{array}$

\begin{tabular}{ccc}
\hline 2016 & 1438 & - \\
\hline 2017 & 1962 & $5.25 \%$ \\
\hline 2018 & 1408 & $-5.54 \%$ \\
\hline 2019 & 2347 & $9.39 \%$
\end{tabular}




$2020 \quad 2324 \quad-0.24 \%$

Sumber: Investing.com \& diolah 2021

Dari tabel yang disajikan diatas menunjukkan bahwasanya pertumbuhan rata-rata harga saham selama 5 tahun terakhir mengalami fluktuaktif naik turun mulai tahun 2017 rerata tumbuh 5.25\%, tahun 2018 mengalami penurunan sebesar $-5.54 \%$, tahun 2019 mengalami kenaikan signifikan sebesar $9.39 \%$ dan kembali mengalami penurunan sebesar -0.24 ditahun 2020. Namun apabila dihitung selama 5 tahun terakhir tersebut harga saham perbankan cenderung mengalami kenaikan. Berdasarkan latar belakang tentang naiknya harga saham perusahaan pada sektor perbankan selama 5 tahun terakhir dan faktor umum penyebab kenaikannnya yang dipandang secara fundamental dari PER dan Dividen Yield tersebut maka peneliti memiliki alasan penelitian untuk meneliti tentang pengaruh PER dan Dividen Yield Terhadap Harga Saham Perusahaan Sektor Perbankan Di Bursa Efek Indonesia.

Rumusan masalah atas uraian latar belakang yang telah disampaikan tadi maka masalah yang ada adalah apakah PER memiliki pengaruh secara parsial terhadap harga saham?, apakah Dividen Yield yang dibagikan perusahaan kepada para investor akan berpengaruh secara parsial terhadap pembentukan harga saham? dan juga apakah secara simultan PER dan Dividen Yield tersebut dapat mempengaruhi harga saham perusahaan sektor perbankan yang terdaftar di BEI?

\section{METODE}

Metode yang digunakan dalam penelitian ini berjenis penelitian kuantitatif dengan menggunakan data sekunder yang mana peneliti memperoleh data dari Bursa Efek Indonesia (BEI) dan website investing.com berupa laporan keuangan yang diterbitkan pada tahun 2020 . Populasi yang digunakan dalam penelitian ini berjenis Populasi Target (Target Population), Populasi Target (Target Population) adalah penentuan populasi yang mana peneliti memiliki ketertarikan pada kelompok ataupun objek yang menarik dan telah ditentukan berdasarkan kelompok untuk menggeneralisasi kesimpulan (Hayati, 2020) sehingga populsi dalam penelitian ini berjumlah 44 yang terdiri dari seluruh perusahaan subsektor perbankan yang terdaftar di BEI.

Sementara untuk sampel dalam penelitian berjenis Sampling Non-Probabilitas yang mana jenis ini tidak menentukan sampel yang dipilih untuk digenerelisasikan (Hayati, 2020).Kriteria yang sampel yang dipilih merupakan perusahaan sektor perbankan yang ditahun 2020 yang membagikan dividend dan nilai PER serta harga saham saham saat akhir tahun 2020. Sehingga sampel dalam penelitian ini berjumlah 16 .

Analisis yang digunakan dalam penelitian ini menggunakan bantuan program Statistical Product and Servisce Solutions (SPSS) versi 20.Adapun instrument teknik analisis adalah dengan menggunakan 2 bagian pengujian yakni asumsi secara klasik dan pengujian hipotesis.

\section{HASILDANPEMBAHASAN}

1. PER tidak berpengaruh terhadap Harga Saham perbankan di BEI tahun 2020 sehingga hipotesis $\mathrm{H}_{1}$ ditolak. Hasil penelitian ini berbeda dengan hasil penelitian (Rahmadewi \& Abundanti, 2018). Hal ini dapat terjadi karena kemungkinan investor tidak terlalu memperhatikan nilai PER saham atau lebih memperhatikan faktor lain seperti EPS dll.

2. Dividen tidak berpengaruh terhadap Harga Saham perbankan di BEI tahun 2020 sehingga hipotesis $\mathrm{H}_{2}$ ditolak. Hasil penelitian ini berbeda dengan hasil penelitian (Fitri et al., 2018). Hal ini dapat terjadi karena investor tidak tertari pada besarnya dividen yield sebagai return imbal hasil investasi melainkan investor tertarik dari return imbal hasil capital gain (selisih harga saham).

3. PER dan Dividen Yield tidak berpengaruh terhadap Harga Saham perbankan di BEI tahun 2020 sehingga Hipotesis $\mathrm{H}_{3}$ ditolak. Hal ini disebabkan karena kemungkinan investor tidak 
terlalu memperhatikan nilai PER saham atau lebih memperhatikan faktor lain seperti EPS dan investor tidak tertari pada besarnya dividen yield sebagai return imbal hasil investasi melainkan investor tertarik dari return imbal hasil capital gain (selisih harga saham) sehingga pada akhirnya tidak memiliki pengaruh secara simultan.

\section{SIMPULAN}

1. Secara parsial PER tidak berpengaruh terhadap Harga Saham perbankan di BEI tahun 2020.

2. Secara parsial Dividen Yield tidak berpengaruh terhadap Harga Saham perbankan di BEI tahun 2020.

3. Secara simultan PER dan Dividen Yield tidak berpengaruh terhadap Harga Saham perbankan di BEI tahun 2020.

\section{DAFTAR PUSTAKA}

AR, M. D., \& Hidayat, R. R. (2015). Analisis Kinerja Investasi Dalam Reksadana Saham (Equity Funds) Dengan Metode Sharpe Dan Treynor. Jurnal Administrasi Bisnis (JAB), 27(1). administrasibisnis.studentjournal.ub.ac.id

Fitri, I. K., Purnamasari, I., Pendidikan, U., \& Fitri, I. K. (2018). Organum: Jurnal Saintifik Manajemen dan Akuntansi Pengaruh Kebijakan Dividen terhadap Harga Saham (Studi pada Perusahaan Pertambangan di Bursa Efek Indonesia). 01(01), 8-14. https://doi.org/10.35138/organu

Ghozali, I. (2016). Aplikasi Analisis Multivariate IBM SPSS 23. Badan Penerbit Universitas Diponegoro.

Hayati, R. (2020). Jenis Populasi dan Sampel dalam Penelitian. Penelitian Ilmiah.Com. https://penelitianilmiah.com/jenis-populasi-dan-sampel/

Hendrata, A. S. (2018). Pengaruh Dividend Yield Terhadap Return Saham Serta Mediasi Price Earning Ratio dan Dividen Payout Ratio pada Pengaruh Earning Per Share Terhadap Return Saham. Universitas Sanata Dharma.

Kurnia, N. (2015). Analisis Pengaruh Debt To Equity Ratio (DER) Dan Net Profit Margin (NPM) Terhadap Harga Saham Pada Perusahaan Sektor Aneka Industri Yang Terdaftar Di Bursa Efek Indonesia Tahun 2011-2013. Politeknik Negeri Sriwijaya.

Mandiri Sekuritas. (2019). Pelajari 6 Rasio Keuangan Berikut untuk Memudahkan Anda dalam Memilih Saham. Mandiri Sekuritas. https://www.most.co.id/tips-investasi/investorpemula-ini-6-rasio-keuangan-untuk-memudahkan-anda-memilih-saham

Novasari, E. (2013). Pengaruh Per, Eps, Roa Dan Der Terhadap Harga Saham Perusahaan SubSektor Industri Textile Yang Go Public Di Bursa Efek Indonesia (Bei) Tahun 2009-2011. In Development (Vol. 134, Issue 4).

Prasetyo, E. (2012). Pengaruh Earning Per Share ( EPS ) Dan Price Earning Ratio ( Per ) Terhadap Harga Saham Pada Perusahaan Lq-45 Yang Terdaftar Di Bursa Efek Indonesia. Universitas Sebelas Maret, 1-60.

Rahmadewi, P. W., \& Abundanti, N. (2018). Pengaruh EPS , PER , CR , DAN ROE Terhadap Harga Saham Di Fakultas Ekonomi dan Bisnis Universitas Udayana, Bali, Indonesia ABSTRAK Penilaian harga saham merupakan hal yang sangat penting dan mendasar bagi para investor sebelum melakukan investasi karena. E-Jurnal Manajemen Unud, Vol. 7, No. 4, 2018: 2106-2133, 7(4), 2106-2133.

Setiawan, S. R. D. (2018, July 10). No Title. Kompas.Com.

Sulia. (2017). Analisis Faktor-Faktor yang Mempengaruhi Harga Saham pada Perusahaan LQ 45 yang Terdaftar Di Bursa Efek Indonesia. Jurnal Wira Ekonomi Mikroskil, 7(2).

Syahyunan. (2015). Manajemen Keuangan (Perencanaan, Analisis dan Pengendalian Keuangan (2nd ed.). USU Press. 